\title{
Костырченко Г.В. Тайная политика: от Брежнева до Горбачева: в 2 ч. Часть І. Власть - Еврейский вопрос - Интеллигенция. Часть II. Советские евреи: выбор будущего.
}

\author{
М.: Международные отношения, 2019. \\ ISBN: 978-5-7133-1619-8. 592 с.; ил.+ 480 с.; ил.
}

DOI: $10.31168 / 2658-3364.2020 .2 .22$

Историк советского еврейства не может, просто не имеет права обойти вниманием многочисленные публикации Геннадия Васильевича Костырченко, которые уже в течение четверти века служат важными, нередко уникальными источниками информации и одновременно становятся катализаторами продуктивных споров в этой области исследований. При этом для книг и статей Костырченко непросто найти место на полке работ еврейских историков, то есть специалистов со знанием соответствующих языков и общего контекста еврейской истории и культуры. В России, как и в большинстве постсоветских стран, доминирует другой жанр академических исследований - о евреях, под углом зрения общей советской истории, преимущественно на базе местных опубликованных и архивных материалов.

Автор книги «Тайная политика: от Брежнева до Горбачева» - несомненный лидер в этом жанре. Костырченко, доктор исторических наук, ведущий научный сотрудник Института российской истории РАН, никогда и не причислял себя к еврейским историкам. Не думаю, что он нуждается в таком причислении. Ведь он изучает не жизнь евреев в СССР, а еврейские аспекты истории СССР. В его работах речь идет, в основном, о том, как советские властные и околовластные лица и структуры относились к «еврейскому вопросу» в целом или к отдельным персоналиям. 
«Тайная политика» рассказывает, например, об опеке, оказываемой Брежневым Аркадию Райкину. (Брежнев, видимо, не знал, что тогда в ходу был анекдот о том, как его в будущем будут описывать энциклопедии: «Политический деятель времен Аркадия Райкина»). В целом ряде случаев историку удается самое сложное - раскрыть тайны механизма принятия решений по тому или иному «еврейскому вопросу».

По мнению Костырченко, позиция, занятая фигурами на советском олимпе или где-то в «олимпийских предгорьях» по отношению к «еврейским вопросам», нередко определялась их известным или скрываемым этническим происхождением. Например, в новой книге много внимания уделяется возможной еврейской «четвертушке» в генетическом древе Юрия Андропова и влиянию тщательно скрываемого квартеронства на политическое поведение главы КГБ, а позже и государства. Мне такого рода увязка кажется спорной и, главное, практически недоказуемой. Странно звучит также фраза о литературном критике Владимире Кардине: «Будучи евреем (выделено мной - Г.Э.), он тем не менее, отверг весьма распространенную мифологему о подготовке Сталиным депортации евреев» [Костырченко 2019, Т. 1, 81]. Непонятно, какую роль в этом случае могла играть национальность Кардина.

Новый 1000-страничный двухтомник хронологически дополняет его предыдущие книги ${ }^{1}$. Главы, написанные как историческое повествование, соседствуют в книге с главами, носящими скорее политологический характер. Особенно интересным мне показался анализ конфликтов в среде публицистов, академических работников и партийных функционеров, занимавшихся - по долгу службы или по зову души - антисионистской и антирелигиозной пропагандой. Не все авторы такого рода литературы переходили границы моральной дозволенности, за которыми антисионистская риторика становилась терминологическим фасадом для откровенно антиеврейской публицистики. Костырченко упоминает и малоизученную, парадоксальную популярность книг на эти темы в еврейской среде. С одной стороны, они все-таки были «о евреях» и несли какие-то крупицы информации, а с другой стороны они злили и тем самым укрепляли «еврейскую обиду».

Среди авторов антисионистской и антирелигиозной литературы было немало евреев. Мне запомнился разговор с профессором философии - их тогда было, кажется, всего двадцать пять во всей Украине. Он узнал, что я

${ }^{1}$ См., в частности: В плену у красного фараона. Политические преследования евреев в последнее сталинское десятилетие. М.: Международные отношения, 1994. 400 с. (американское издание «Out of the Red Shadows: Anti-Semitism in Stalin's Russia» - 1995; французское издание «Prisonniers du Pharaon Rouge» - 1998); Тайная политика Сталина. Власть и антисемитизм. М.: Международные отношения, 2001 (2-е изд. - 2003); Тайная политика Хрущёва: власть, интеллигенция, еврейский вопрос. М.: Международные отношения, 2012. - Прим. ред. 
перешел работать в московский еврейский журнал Советиш геймланд, и поэтому попросил меня проверить, была ли в нем напечатана рецензия на его антисионистские труды. По его утверждению, труды эти отличались объективностью. Рецензию я не нашел, а позже узнал, что вопрос был задан, когда профессор и вся его семья уже сидели на чемоданах. В Израиле он читал лекции по истории сионизма для репатриантов. Туда же, в Израиль, в конце концов переехал и Моисей Беленький, автор атеистической литературы, критиковавший иудаизм с марксистской точки зрения. Там он смог, по всей видимости, убедиться, что его комментарии о жизни в еврейском государстве (о том, например, что женщины лишены ряда гражданских прав, а необрезанный мужчина не может стать гражданином Израиля) были лишены основания.

Взаимоотношения между антисионистами разных мастей заняли такой объем текста, что автору, по всей видимости, пришлось пожертвовать другими важными сюжетами. В частности, мало внимания уделяется Еврейской автономной области, хотя идеологический аппарат отводил этому территориальному образованию довольно заметную роль в официальной пропаганде, нацеленной не столько на советскую, сколько на зарубежную аудиторию. «Биробиджанизация» советской политики, особенно во второй половине ХХ в., все еще остается за кадром серьезных исследований, хотя именно псевдо-успехами еврейского национального строительства на Дальнем Востоке кремлевские идеологи упорно пытались прикрыть, как фиговым листком, бесстыдство своего нежелания и неумения каким-то образом найти подход к созданию психологически комфортного и социально приемлемого климата для жизни евреев в СССР.

Хуже придумать было сложно: перевести евреев в разряд этнических групп, наделенных титульной территорией, и тем самым как бы «нормализовать» их, загнав в прокрустово ложе советской схемы решения национального вопроса. Хочешь быть евреем и получать от этого удовольствие - дуй в Биробиджан. Иначе ты обитаешь в разбросанной по СССР диаспоре Биробиджана и получаешь то, что получает какой-нибудь украинец или литовец за пределами своей республики, а именно возможность подписаться на газету, издаваемую в этнической метрополии (у евреев - у них ведь всегда привилегии! - еще и на московский Советиш геймланд), посещать время от времени концерты, покупать книги на еврейском языке или в переводе с него, и что-нибудь еще в этом духе. А в Биробиджане, если ты туда поедешь, у тебя есть шанс местного карьерного роста вплоть до секретаря обкома. Можно даже стать депутатом Верховного Совета - было в нем, как в иранском меджлисе, соответствующее место. И за пределами советско-еврейского национального очага у биробиджанца был шанс добиться успеха. Эммануил Казакевич и Арон Вергелис, биробиджанские поэты (правда, 
оба к тому времени уже жили в Москве), стали в один и тот же день в 1940 г. членами Союза писателей. Вергелис возглавит в 1961 г. Советиш геймланд, а другого биробиджанца, Адольфа Шаевича, тоже из рядов ленинского комсомола, в 1980 г. поставят во главе московской синагоя ги. В 1977 г. создание как бы биробиджанского Камерного еврейского музыкального театра под руководством (все-таки не биробиджанца) Юрия Шерлинга зеркально и грозно ответит американцам на введение поправки Джексона-Вэника.

К этой территориальной схеме была еще одна интересная добавка: «пятый пункт», причем не по выбору, как это было до конца 1930-х годов, не по «зову крови», а сугубо по ее составу. Если состав стопроцентный, то есть и мама, и папа евреи, то уж будь добр носить эту метку, даже если ты понятия не имеешь, в чем ты по своей культуре отличаешься от нееврейского соседа по парте. Государство делало все возможное, чтобы аккультурировать евреев, но при этом бюрократически их не ассимилировать, а вместо этого держать их в категории граждан с врожденным и (за редким исключением) неисправимым анкетным изъяном, создающим преграды - реальные или пусть только воображаемые - на пути к поступлению куда-то и получению чего-то. К моему счастью, я относился к той части советского еврейства, которая выросла в семьях, где еврейская культура в какой-то форме жила, поэтому эта «метка» считалась не изъяном, а просто отражением реальности и даже предметом гордости, особенно в случае преодоления преград.

Однако у меня нет сомнений, что многие тысячи евреев были бы рады избавиться от, как тогда говорили, «пятой группы инвалидности». Кто-то действительно избавлялся через связи и взятки. Или «виртуально» - через крещение. Но главных идеологов свобода выбора (не только евреями, конечно) «пятого пункта» почему-то не устраивала. По сути, в этом и заключалась одна из «тайн Полишинеля» советской политики по отношению к евреям, политики, толкавшей к выезду. Мне представляется неслучайным то, что среди лидеров-отказников заметно выделялись люди из тщательно аккультурированных семей. Приходилось слышать, что были и такие, кто видел в эмиграции возможность «перестать быть евреями». В целом, причин и поводов для отъезда было много. К их числу относилось и следующее: человеку, мечтавшему о жизни в большом культурном центре, с широкими возможностями для профессионального роста и развития, но судьбой заброшенному, скажем, в Большой Токмак или Бендеры, обычно куда легче было перебраться в Иерусалим или Нью-Йорк, чем в забаррикадированные системой прописки Москву и Ленинград.

Эмиграция - одна из основных тем книги. Особое внимание уделяется отказнику, вынужденному, по мнению Костырченко, «влачить по воле властей жалкое существование изгоя, лишенного работы по специаль- 
ности, достигнутого социального статуса и связанных с ним льгот и услуг в сферах медицины, образования, обеспечения ширпотребом и пр.» [Костырченко 2019, т. 2, 163]. Это правда. Но не для всех отказников. Сошлюсь на свой опыт. Благодаря порядочности руководства того института, в котором я работал, мне ритуально попортили нервы, исключили из комсомола и народной дружины, но не выбросили на улицу. Более того, через пару лет, после двух отказов по причине кем-то установленной «нецелесообразности» моего выезда, даже стали повышать в должности. В результате, я причисляю себя и себе подобных к категории refusenik light. Изгоем я себя тоже не ощущал. Скорее, подача документов принесла ощущение свободы.

При всей несомненной полезности и новизне «Тайн политики» у меня по ходу чтения росла досада по отношению к издательству «Международные отношения». Самое главное - рукописи надо все-таки посылать компетентным экспертам и привлекать к работе надежного научного редактора. Нет сомнений, что в этом случае текст, насыщенный биографическими и событийными подробностями, очистился бы от досадных ошибок. Кто-то из экспертов, например, удержал бы автора от ссылок на антисионистскую литературу советского периода как на источник информации о событиях того времени. Кто-то бы усомнился, что Вергелис заплатил «за свою свободу и жизнь жесткой критикой арестованных после войны коллег по цеху еврейской литературы» [Костырченко 2019, T. 1, 61], и подсказал бы, что его «notitsn on a seyder» переводятся на русский язык как «беспорядочные заметки», а не «заметки к сейдеру» [Костырченко 2019, Т. 1, 530]. Кого-то бы озадачила информация о том, что «в одном из крупных проектно-строительных институтов Москвы <...> штатно работало примерно 3 тыс. евреев» [Костырченко 2019, Т. 2, 305]. Что же это был за такой институт?

Полезно было бы проверить многочисленные вторичные ссылки, то есть те, которые перекочевали из других публикаций. Я никогда не читал ничего, написанного политологом Лионелем Дадиани. Он время от времени появлялся в редакции Советиш геймланд и был мне симпатичен как человек. Однако его ссылка на статью в Нью-Йорк таймс меня никуда не привела [Костырченко 2019, Т. 2, 173]. Я не сомневаюсь, что эксперты помогли бы Геннадию Васильевичу уточнить главы о Советиш геймланд и о еврейских организациях конца 1980-х - начала 1990-х гг. «Я сам там был», и поэтому знаю, что картина выглядела как-то иначе.

Аркадий Райкин писал в своих воспоминаниях: «Когда приходит ясность осознания исторической правды, то и свою собственную жизнь осознаешь как бы частичкой этой правды, частичкой истории. Но вместе с тем многое уже не можешь восстановить. Не потому, что каких-то фактов не помнишь. А потому, что твое тогдашнее жизнеощущение теперь представляется тебе странным, даже загадочным». [Райкин 2014, 153]. 
Новая книга Костырченко - это не только подспорье для историков, изучающих последние десятилетия СССР, но и полезная литература для широкого круга читателей, многим она поможет осознать свою жизнь как бы частичкой истории.

\title{
Литература
}

Райкин 2014 - Райкин А.И. Без грима: воспоминания. М.: Центрополиграф, 2014. $332 \mathrm{c}$.

Костырченко 2019 - Костырченко Г.В. Тайная политика: от Брежнева до Горбачева: в 2 ч. Часть I. Власть - Еврейский вопрос - Интеллигенция. Часть II. Советские евреи: выбор будущего. М.: Международные отношения, 2019. 592 с.; ил.+ 480 с.; ил.

\author{
Gennady Estraikh (New York, USA) \\ $\mathrm{PhD}$ \\ Skirball Department of Hebrew and Judaic Studies, New York University \\ E-mail:ge293@nyu.edu \\ ORCID ID: 0000-0002-7885-7851
}

